\title{
Strategi Peningkatan Penghimpunan Wakaf Melalui Kegiatan Dakwah di Pesantren Baitul Hidayah
}

\author{
Hendi Suhendi ${ }^{1}$, M. Fauzi Arif ${ }^{2}$, N Sausan M. Sholeh ${ }^{3}$ \\ 1,2,3 Komunikasi dan Penyiaran Islam Fakultas Dakwah \\ Universitas Islam Bandung \\ Bandung, Indonesia \\ Email: ${ }^{1}$ hendisf.unisba@gmail.com, ${ }^{2}$ muhammadfauziarif@gmail.com, \\ ${ }^{3}$ sausan.muhammad@unisba.ac.id
}

\begin{abstract}
This study examines strategies to increase the collection of waqf through Islamic Da'wah activities. This is important to do, considering the Baitul Hidayah Islamic Boarding School has a large potential for waqf while the ongoing collection of waqf has not yet reached the expected target. This study aims to find a solution in the form of a strategy to increase the collection of waqf by utilizing da'wah activities as a way of socialization and promotion. This type of research is a qualitative descriptive study, while the data sources are obtained directly in the field (field research). The research approach uses case studies with data collection techniques through interviews, documentation studies and field observations. The results of this study recommend strategies for increasing the collection of waqf through: (i) Optimizing the role of dai as a marketing of waqf. (ii) fulltime managing human resources. (iii) Improvement of Facilities and Infrastructure. (iv) Creating a creative collection program. (v) Standardization of Data Management. (vi) Improvement of convenience services and activity reports.
\end{abstract}

Keywords: Collection, Waqf, Da'wah and Islamic boarding schools.

\begin{abstract}
ABSTRAK
Penelitian ini mengkaji tentang strategi peningkatan penghimpunan wakaf melalui kegiatan Dakwah Islam. Hal ini penting dilakukan, mengingat Pesantren Baitul Hidayah memiliki potensi wakaf yang cukup besar sementara penghimpunan wakaf yang berjalan belum mencapai target yang diharapkan. Penelitian ini bertujuan untuk mendapatkan solusi berupa strategi peningkatan penghimpunan wakaf dengan memanfaatkan kegiatan-kegiatan dakwah sebagai jalan sosialisasi dan promosi. Jenis penelitian ini adalah penelitian deskriptif kualitatif, adapun sumber data diperoleh langsung di lapangan (field research). Pendekatan penelitian menggunakan studi kasus dengan teknik pengumpulan data melalui wawancara, studi dokumentasi dan observasi lapangan. Hasil penelitian merekomendasikan strategi peningkatan penghimpunan wakaf melalui : (i) Optimalisasi peran dai sebagai marketing wakaf. (ii) SDM pengelola fulltime. (iii) Peningkatan Sarana dan Prasarana. (iv) Menciptakan Program penghimpunan yang kreatif. (v) Standarisasi Pengelolaan Data. (vi) Peningkatan layanan kemudahan dan laporan kegiatan.
\end{abstract}

Kata Kunci: Penghimpunan, Wakaf, Dakwah dan Pesantren.

\section{PENDAHULUAN}

\section{Latar Belakang}

Pondok Pesantren Baitul Hidayah merupakan pondok modern yang memiliki visi mewujudkan insan yang bertakwa, berakhlak Islam, kuat dan mandiri. Pesantren berbasis wakaf ini berdiri di tanah wakaf seluas 3,5 Ha sejak tahun 2009. Perkembangan pesantren sampai saat ini banyak ditopang dari dana masyarakat salah satunya wakaf. 
Seiring dengan peningkatan jumlah santri, maka kebutuhan sarana dan prasarana serta biaya operasional juga meningkat. Kondisi tersebut mendorong para pengurus pesantren untuk serius melakukan pengelolaan dana wakaf melalui upaya pembentukan unit pengelola wakaf yang diinisiasi dan dikembangkan dengan tim PKM LPPM Unisba sejak tahun 2017 melalui tiga kali pelaksanaan program Pengabdian Kepada Masyarakat (PKM) (Khuza'i dkk, 2019).

Wakaf tunai merupakan instrumen keuangan dalam sistem perekonomian Islam telah terbukti mendorong kesejahtraan masyarakat (Shaikh, S. A., Ismail, A. G., \& Shafiai, 2017). Meningkatkan indek pembangunan manusia (Mohamad, F. dkk, 2014). Dapat mengurangi kemiskinan (Sadeq, A. M. 2002). Serta dapat meningkatkan sosio-ekonomi (Ridwan, 2018). Dengan demikian wakaf tunai dapat dijadikan sumber keuangan Pesantren Baitul Hidayah dalam memenuhi kebutuhan pendidikan dan dakwah.

Potensi wakaf secara umum di Indonesia sangat tinggi, pada tahun 2007 mencapai nilai 3 triliyun (Departemen Agama, 2007). Berdasarkan studi pendahuluan, Pesanten Baitul Hidayah memiliki potensi wakaf yang cukup besar diantaranya asset tanah 3,5 $\mathrm{H}$ yang dapat diproduktifkan. Jaringan perusahaan yang selama ini berdonasi. Aktivitas dakwah 10 orang ustad dengan jemaah lebih dari 1000 orang di 20 pengajian yang berbeda. Serta lebih dari 500 jemaah haji dan umroh yang setiap tahun dibimbing oleh 9 ustad Baitul Hidayah. Orangtua wali satri sebanyak 332 orang. Potensi tersebut jika dikelola secara professional dan proporsional akan berdampak positif pada kebangkitan perekonomian pesantren (Kasdi, 2015).

Namun, realita penghimpunan wakaf yang diperoleh belum signifikan, November tahun 2020 terhimpun dana wakaf sebesar Rp 40.000.000,-. Jumlah tersebut sangat kecil dibandingkan dengan kebutuhan sarana dan operasional lebih dari 200 juta per bulan. Sebagian kebutuhan tersebut diperoleh dari iuran makan santri sebesar 400.000/santri/bulan, akan tetapi nilainya masih jauh dari cukup.

Sementara, potensi wakaf jika dilihat dari sasaran muwakif yang ada nilainya cukup besar. Sederhanya, jika jumlah jemaah pengajian, jemaah haji umroh, wali santri serta mitramitra perusahaan yang berjumlah lebih dari 2357 orang bisa diyakinkan untuk berwakaf setiap bulan senilai Rp 100.000/orang, maka potensi wakaf bulanan sebesar Rp 235.700.000.

Fenomena ini, menggugah kegelisahan akademik peneliti untuk melakukan penelitian tentang pengelolaan wakaf yang difokuskan pada penggalian data tentang perolehan wakaf, pola penghimpunan wakaf, kegiatan dakwah dan kemudian dianalisis untuk merumuskan strategi peningkatan penghimpunan wakaf melalui kegiatan dakwah di Pesantren Baitul Hidayah.

Adapun metode penelitian yang digunakan adalah deskriptif kualitatif, dengan sumber data diperoleh langsung di lapangan (field research). Teknik pengumpulan data pada penelitian ini menggunakan metode wawancara, observasi dan dokumentasi. Teknik pengolahan datanya menggunakan teknik triangulasi dan audit, dimana data yang telah didapatkan diperiksa kembali keabsahannya melalui pengecekan silang atau perbandingan data dengan sumber data ganda/berbeda. Jika terdapat perbedaan data, maka akan dicari sumber data yang dianggap paling akurat (Maleong, 1990).

\section{Identifikasi Masalah}

Hasil penghimpunan wakaf yang belum optimal dibandingkan dengan peluang yang ada, merupakan masalah yang perlu dicarikan solusinya. Kondisi tersebut disebabkan belum maksimal proses penghimpunan wakaf yang dilakukan oleh Pesantren Baitul Hidayah dari aspek penyusunan program, sosialisasi, layanan penghimpunan, laporan pelaksanaan program 
serta pemanfaatan kegiatan dakwah. Berdasarkan identifikasi masalah tersebut, maka penelitian ini bentujuan untuk menemukan strategi penghimpunan wakaf melalui kegiatan dakwah.

\section{Rumusan Masalah}

Merujuk pada latar belakang masalah diatas maka rumusan masalah penelitian ini yaitu bagaimana perolehan dan pengelolaan penghimpunan wakaf, bagaimana kegiatan dakwah dan bagaimana strategi peningkatan penghimpunan wakaf melalui kegiatan dakwah di Pesantren Baitul Hidayah.

\section{LANDASAN TEORI}

\section{Strategi}

Strategi merupakan istilah yang umum dalam membentuk sistematika yang perlu diciptakan dalam suatu pengelolaan organisasi, strategi pada dasarnya merupakan seni dan ilmu menggunakan dan mengembangkan kekuatan untuk mencapai tujuan yang telah ditetapkan sebelumnya (Chaniago, 2014) Menurut David, strategi adalah sarana bersama dengan tujuan jangka panjang yang akan hendak dicapai. (Faruq dkk, 2014).

Strategi merupakan istilah yang sering diidentikkan dengan "taktik" yang secara bahasa dapat diartikan sebagai corcerning the movement of organism in respons to external stimulus (suatu yang terkait dengan gerakan organisme dalam menjawab stimulus dari luar). Sementara itu, secara konseptual strategi dapat dipahami sebagai suatu garis besar haluan dalam bertindak untuk mencapai sasaran yang telah ditentukan (Pimay, 2005)

\section{Penghimpunan atau Fundraising Dana}

Fundraising merupakan aktivitas penghimpunan baik dari masyarakat secara individu, kelompok ataupun dari organisasi. Fundraising merupakan upaya jemput bola dalam rangka menggali dan mengoptimalkan potensi yang ada di masyarakat baik berupa uang, tanah, bangunan, peralatan, kendaraan dan asset lainnya. Fundrasing adalah aktivitas awal dalam alur manajemen tatakelola wakaf, yang kemudian dilanjutkan dengan pengelolaan harta serta pendayagunaan sesuai syariat dan peraturan yang telah ada.

(Faradis, dkk 2015), menyatakan bahwa Fundraising merupakan pengumpulan dana. Fundraising Campain berarti kampanye pengumpulan dana. Fundraising juga dapat diartikan sebagai kegiatan dalam rangka menghimpun dana dari masyarakat dan sumber daya lainnya dari masyarakat (baik individu, kelompok, organisasi, perusahaan ataupun pemerintah) yang akan digunakan untuk membiayai program dan kegiatan operasional organisasi/lembaga sehingga mencapai tujuannya. Adapun tujuan yang dimaksud adalah pengumpulan dana, penambahan muwakif, peningkatan citra lembaga serta membangun loyalitas muwakif melalui beberapa unsur diantaranya : kebutuhan wakif, segmentasi, positioning, produk, harga dan biaya transaksi, promosi, serta maintenance. Meningkatkan penghimpunan wakaf dapat dilakukan dengan beberapa kegiatan mulai dari perbaikan kelembagaan, sosialisasi dan promosi serta layanan kemudahan bagi para donatur atau calon donatur (Suhendi, 2018).

\section{Wakaf}

Secara kebahasaan wakaf bermakna berhenti atau berdiri (waqafa/yaqifu/wakafan), secara istilah syara' wakaf adalah menahan harta yang mungkin diambil manfaatnya tanpa menghabiskan atau merusakkan bendanya (ainnya) dan digunakan untuk kebaikan. Benda wakaf bersifat tidak dapat dimiliki secara pribadi atau perorangan (mal mahjur), benda wakaf merupakan milik Allah SWT yang diamanatkan menjadi kepentingan umum dengan tujuan 
yang spesifik (Huda, 2012). Menurut Jumhur Ulama wakaf adalah menahan suatu benda yang dapat dimanfaatkan, sementara 'ain asset tetap, tidak hilang atau berkurang, karena diambil benefit-nya sepanjang penggunaan harta itu diperbolehkan menurut hukum Islam (Huda \& Heykal, 2010).

Jumhur Ulama selain Imam Hanifah menyatakan rukun wakaf terdiri dari: (1) wakif, (2) maukuf bih, (3) maukuf alaih dan shigat. Menurut Imam Hanifah, apabila shigat telah diucapkan suatu perbuatan wakaf sah secara hukum karena unsur rukun hanya berupa pengucapan shigat. Peraturan Pemerintah No.28 Tahun 1977 dan Inpres No.1 Tahun 1991 menyatakan, selain mengharuskan keberadaan empat rukun wakaf tersebut, juga menetukan kehadiran nadzir, saksi dan PPAIW (Pejabat Pembuat Akta Ikrar Wakaf) dalam ikatan wakaf.

\section{Dakwah}

Dakwah adalah segala usaha dan kegiatan yang disengaja dan berencana dalam wujud sikap, ucapan yang mengandung ajakan dan seruan, baik langsung maupun tidak langsung ditujukan kepada perorangan, masyarakat maupun golongan supaya tergugah jiwanya kepada ajaran Islam untuk selanjutnya mempelajari dan menghayati dan mengamalkannya dalam kehidupan sehari-hari (Siddiq, 1987).

Berdasarkan pada pengertian tersebut maka pada prinsipnya dakwah dapat menggerakan orang untuk melakukan amal sholeh salah satunya dengan mengeluarkan sebagian hartanya untuk diwakafkan. Sehingga dakwah kegiatan-kegiatan dakwah dapat dijadikan bagian dari upaya peningkatan penghimpunan wakaf. Namun agar tujuan dakwah dapat tercapai dengan baik, harus memperhatikan unsur-unsur dakwah diantaranya (Azis, 2004) : Da'i (Pelaku dakwah), Mad'u (Mitra dakwah), Materi (Pesan dakwah), Wasilah (Media dakwah), Thariqah (Metode dakwah), dan Atsar ( Efek dakwah).

\section{METODE PENELITIAN}

Jenis penelitian ini adalah penelitian deskriptif kualitatif, adapun sumber data diperoleh langsung di lapangan (field research). Pendekatan penelitian ini menggunakan studi kasus, secara rinci penelitian ini menggambarkan penghimpunan wakaf, potensi wakaf dan kegiatan dakwah Islam di Pesantren Baitul Hidayah. Selanjutnya mengkaji secara sistematis tentang strategi peningkatan penghimpunan wakaf melalui kegiatan dakwah. Penelitian ini juga bersifat evaluatif, maksudnya selain menggambarkan permasalahan dan menganalisanya, juga mengevaluasi kelebihan dan kekurangan kegiatan penghimpunan wakaf yang sudah berjalan.

Teknik pengumpulan data pada penelitian ini menggunakan metode wawancara, observasi dan dokumentasi. Adapun teknik pengolahan datanya menggunakan teknik triangulasi dan audit, dimana data yang telah didapatkan diperiksa kembali keabsahannya melalui pengecekan silang atau perbandingan data dengan sumber data ganda/berbeda. Jika terdapat perbedaan data, maka akan dicari sumber data yang dianggap paling akurat (Maleong, 1990).

\section{PEMBAHASAN}

\section{Penghimpunan Wakaf Pesantren Baitul Hidayah}

Pesantren Baitul Hidayah didirikan sejak tahun 2009 atas dukungan seorang muwakif yang mewakafkan tanah 3,5 Ha beserta dana pembangunan awal pesantren. Pesantren yang berafiliasi kepada Pondok Modern Daarussalam Gontor itu sampai saat ini tidak memberlakukan iuran SPP bulanan, setiap santri hanya membayar biaya makan sebesar Rp 400.000 setiap bulan. Kegiatan operasional pendidikan pesantren bertumpu pada dana infak sedekah zakat dan wakaf dari masyarakat khususnya jemaah pengajian. 
Untuk itu, Pesantren Baitul Hidayah berupaya meningkatkan optimalisasi wakaf melalui pembentukan lembaga wakaf Pesantren Baitul Hidayah dengan nama Wakaf Foundation pada tahun 2018. Pembentukan lembaga wakaf didasari pada kebutuhan biaya sarana dan prasarana Pendidikan serta potensi wakaf yang cukup besar di masyarakat.

Dengan dukungan berbagai pihak salah satunya para dosen Universitas Islam Bandung menjadikan Wakaf Foundation terus berbenah secara manajerial sampai saat ini. Pengembangan pengelolaan dilakukan dalam tiga bidang yakni penghimpunan, pengelolaan keuangan dan pendayagunaan wakaf. Penghimpunan dikembangkan dalam aspek edukasi, promosi, dan layanan kemudahan donasi.

Hasil pemetaan dan pengolahan data, terdapat 2357 orang yang berpotensi sebagai calon donator Wakaf Foundation diantaranya : Jemaah pengajian 1355 orang, Jemaah umroh 650 orang, wali santri 332 orang, dan donatur yang sudah terdata ada 20 orang. Berdasarkan wawancara dengan Jemaah pengajian terdapat $90 \%$ Jemaah yang mau dan siap untuk terlibat sebagai donator di Pesantren Baitul Hidayah. Besarnya potensi tersebut harus dioptimalkan agar penghimpunan setiap tahun mencapai target dan terus meningkat, terutama potensi yang ada pada jemaah pengajian. Dengan demikian aktivitas dakwah yang dilakukan oleh para ustad harus seiring dengan pola penghimpunan dana wakaf.

Perolehan wakaf dalam 3 tahun terakhir sebagai berikut : tahun 2018 target sebesar 3 Milyar realisasi penghimpunan sebesar 1,55 Milyar atau 52\% dari target. Target tahun 2019 sebesar 2 Milyar, realisasi sebesar 1,1 Milyar atau 55\% dari target. Sedangkan tahun 2020 targetnya 2,5 milyar, realisasinya sebesar 2,8 Milyar atau $112 \%$. Tercapainya target tahun 2020 karena adanya wakaf kendaraan mobil operasional dan wakaf untuk pembangunan asrama.

Pengelolaan wakaf Pesantren Baitul Hidayah saat ini masih dikelola oleh pengurus Yayasan dengan peran utamanya sebagai guru pesantren bukan khusus mengelola wakaf, dibantu oleh 5 orang relawan. Penghimpunan masih bersifat personal yakni kedekatan kepada para ustad, bukan berbasis pada program penghimpunan yang disusun secara sistematis menarik dan bersifat kelembagaan. Selain nilai kepercayaan kepada lembaga, program merupakan landasan seseorang ikut berwakaf dilembaga tersebut. (Purwakananta, 2010).

Administrasi keuangan dan pendataan donatur belum dilakukan secara sitematis melalui pengelolaan data yang baik dan benar sesuai standar umum lembaga sosial. Sehingga peran Wakaf Foundation sebagai lembaga belum berjalan dengan baik. selain itu layanan kemudahan donasi serta pelaporan kegiatan kepada para donator masih menjadi bagian yang diharapkan perbaiknnya oleh para donatur. Kondisi tersebut menunjukan belum optimalnya layanan kemudahan serta pelaporan kegiatan.

Untuk itu, dibutuhkan komitmen besar dari semua pengurus Pesantren agar lembaga Wakaf Foundation bisa berjalan dengan optimal. Sehingga potensi donasi yang ada bisa diraih dengan maksimal dan berdampak pada terpenuhinya kebutuhan operasional kegiatan Pendidikan Pesantren Baitul Hidayah.

\section{Aktivitas Dakwah Pesantren Baitul Hidayah}

Pesantren sebagai lembaga Pendidikan sekaligus lembaga dakwah Islam memiliki tugas untuk meyampaikan risalah Islam kepada para santri dan masyarakat secara luas. Pesantren dituntut mempunyai metode dalam proses pengajarannya sebagai upaya dakwah 
yang transformatif (Asror, 2014). Untuk itu, Pesantren Baitul Hidayah sejak 2009 terus bergerak, berupaya melakukan dakwah kepada para santri, wali santri dan masyarakat umum.

Proses dakwah tersebut dilakukan oleh para ustad dipesantren secara rutin. Sebanyak 8 orang ustad Pesantren Baitul Hidayah melakukan kegiatan dakwah rata-rata setiap orang 3 kali perbulan. Secara umum kegiatan dakwah dilakukan dalam bentuk ceramah Islam berupa pengajian di majlis taklim dalam pesantren dan luar pesantren. Dakwah di pesantren dilakukan kepada 332 santri pada proses pembelajaran harian setiap mata pelajaran. Kemudian pengajian wali santri yang dilakukan satu bulan sekali pada hari minggu pekan keempat saat kunjungan orangtua santri. Saat ini pesantren tetap berupaya untuk melakukan dakwah kepada wali satri secara online.

Kegiatan dakwah kepada masyarakat diluar pesantren terdiri dari jemaah pengajian sebanyak 1355 orang dari 24 majlis taklim, jemaah umroh sebanyak 650 orang dan 20 orang donatur wakaf. Kegiatan tersebut dilakukan di masjid-mesjid lingkungan masyarakat sekitar pesantren, dalam pertemuan alumni jemaah umroh dan juga silaturahmi donator wakaf Pesantren Baitul Hidayah.

Meteri-materi yang disampaikan dalam kegiatan dakwah diantaranya : Tauhid, fiqh, akhlak, muamalah, hadits, tafsir Al-quran, dan adab. Adapun materi yang paling sering disampaikan dari semua ustad berkaitan dengan muamalah dan akhlak. Kedua materi tersebut sering disampaikan karena dinilai penting oleh para ustad, dimana saat ini akhlak masyarakat secara umum harus diperbaiki serta aktivitas muamalah juga harus diluruskan.

\section{Strategi Peningkatan Penghimpunan Wakaf Melalui Kegiatan Dakwah}

Hasil analisis data yang terhimpun dari lapangan baik berupa dokumen, hasil observasi ataupun hasil wawancara yang kemudian dipetakan, menunjukan bahwa terdapat potensi besar wakaf yang ada di para jemaah pengajian. Hal itu ditunjukan dengan hasil wawancara bahwa $90 \%$ Jemaah mau dan siap untuk ikut terlibat dalam program wakaf di Pesantren Baitul Hidayah. Akan tetapi proses pengelolaan wakaf yang dilakukan di Pesantren Baitul Hidayah masih belum optimal terlihat dari capaian prolehan wakaf dalam 3 tahun terakhir masih belum mencapai target yang ditentukan. Kemudian pengelolaan data donatur belum dilakukan dengan baik.

Dengan demikian, untuk mencapai target penghimpunan wakaf dengan optimal berdasar pada potensi yang ada, maka Pesantren Baitul Hidayah perlu melakukan strategi penghimpunan yang sistematis yaitu : Pertama, Optimalisasi peran dai sebagai marketing wakaf. Pesantren Baitul Hidayah yang belum memiliki SDM khusus marketing wakaf maka langkah efektif yang dapat diambil dengan cara memberikan tugas tambahan kepada para ustad pesantren yang biasa mengisi pengajian di masyarakat. Para da'i perlu di berikan arahan dan pemahaman tentang penghimpunan wakaf sehingga meteri-materi yang disampaikan bisa selaras dengan kegiatan penghimpunan wakaf. Berdasarkan wawancara, para da'i lebih banyak memberikan materi akhlak dibandingkan dengan fiqh zakat infak wakaf. Sebagian Jemaah pengajian menyampaikan bahwa mereka membutuhkan materi wakaf sebagai upaya meningkatkan pemahamannya dan juga dorongan untuk berkontribusi melalui wakaf dalam kegiatan pendidikan pesantren.

Optimalisasi peran dai memiliki kekuatan tersendiri untuk menarik donatur khususnya dari jemaah pengajian, karena para dai bisa dijadikan simbol asosiasi dengan membawa brand Baitul Hidayah. Kekuatan asosiasi merk memiliki pengaruh positif dan signifikan dalam persaingan (Sukirman, 2020). Selain itu, para dai bisa dijadikan sebagai marketing public relation yang dapat menarik kepercayaan masyarakat untuk menitipkan donasinya di Baitul 
Hidayah. Karena marketing public relation berdapkan positif dalam pengembangan sebuah lembaga (Syaifulloh, 2021).

Kedua, SDM pengelola fulltime. SDM adalah modal dan kekayaan yang terpenting dari setiap kegiatan organisasi termasuk di pesantren dalam pengelolaan wakaf. Peningkatan penghimpunan wakaf di Pesantren Baitul Hidayah harus di dukung dengan SDM yang fokus bekerja secara penuh waktu. Sehingga proses penghimpunan dapat dilakukan secara sistematis dan terukur mulai dari menciptakan program yang kreatif. sosialisasi, promosi, pelayanan dan pelaporan program. Berdasarkan pengamatan penelitian bahwa, pengelolaan wakaf di Pesantren Baitul Hidayah baru dijalankan oleh pengurus Yayasan sebagai kegiatan tambahan diluar aktivitas mengajar. Untuk itu, kehadiran SDM yang fulltime dalam pengelolaan wakaf di pesantren mejadi kebutuhan prioritas.

Ketiga, peningkatan sarana dan prasarana. Kelancaran kegiatan sebuah organisasi membutuhkan dukungan sarana dan prasarana yang memadai. Dengan demikian, Pesantren Baitul Hidayah secara bertahap harus berusaha memenuhi kebutuhan sarana prasarana dalam pengelolaan wakaf seperti ruang kantor, komputer, peralatan komunikasi, ATK dan lain-lain. Keempat, menciptakan program penghimpunan yang keratif. Program wakaf adalah produk yang akan ditawarkan kepada masyarakat. Untuk itu, harus dibuat dengan menarik, keratif, inovatif, dan solutif. Program harus mampu menjawab kebutuhan dan menyelesaikan permasalahan yang ada di masyarakat. Sebab, saat ini menawarkan program wakaf dengan mengedepankan hanya nilai-nilai agama seperti pahala tidak cukup. Hasil pengamatan beberapa lembaga wakaf yang menghasilkan penghimpunan besar mayoritas di dukung program yang memiliki multiflier effect bagi donatur dan masyarakat secara umum. Lembaga wakaf tersebut memposisikan program sebagai kunci keberhasilan dalam peningkatan penghimpunan wakaf dari tahun ketahun.

Kelima, Standarisasi Pengelolaan Data. Pengelolaan data yang baik menjadi dasar dalam melakukan sebuah analisis penghimpunan wakaf. Pesantren Baitul Hidayah saat ini belum melakukan pengelolaan data secara sistematis dan terstruktur. data-data yang dimaksud diantaranya : data donatur yang berkaitan dengan demografi, kebiasaaan donasi, harapan dan kebutuhan mereka dalam menyalurkan donasi wakaf. Data penghimpunan dana, penyaluran dana operasional dan penggunaan dana untuk program-program wakaf. Data-data tersebut sangat penting sebagai modal untuk mewujudkan pengelolaan wakaf yang acountlabel dan transparan. Selain itu, data dapat dijadikan bahan untuk menentukan program yang akan dijalankan, serta strategi yang tepat dalam proses penghimpunan wakafnya.

Kebutuhan masyarakat di Era Industri 4.0 ini, bukan hanya sekedar ada data-data tersebut, tetapi harus mudah dikases oleh masyarakat secara luas. Mudah dibaca dan dipahami serta menarik dalam tampilannya sehingga dapat menyentuh hati masyarakat yang kemudian mendorong mereka untuk turut serta dalam program-program wakaf yang dijalankan. Untuk memenuhi kebutuhan tersebut salah satunya dibutuhkan website yang menginformasikan secara lengkap keseluruhan kegiatan wakaf di Pesantren Baitul Hidayah.

Keenam, Peningkatan layanan kemudahan dan laporan kegiatan. Layanan kemudahan yang dimaksud adalah kemudahan bagi masyarakat khususnya donatur dan calon donatur untuk mendapatkan informasi secara lengkap tentang kegiatan wakaf di Pesantren Baitul Hidayah. Kemudahan untuk menyalurkan donasi wakaf, baik dilakukan dengan cara datang kelokasi, jemput wakaf atau transfer donasi.

Kehadiran kantor layanan yang mudah dijangkau, representatif, aman dan nyaman menjadi penting dalam memberikan layanan kemudahan bagi para donatur. Kemudian adanya 
tim khusus layanan jemput wakaf yang dapat bekerja penuh waktu menjadi bagian yang perlu diperhatikan oleh Pesantren Baitul Hidayah. Selain itu, ketersediaan nomor rekening bank atau account pembayaran lainnya untuk transfer donasi secara mudah harus segera disediakan. Mengingat saat ini masyarakat lebih banyak menggunakan smart phone yang dapat mereka gunakan untuk sarana pemenuhan kebutuhan termasuk dalam mewujudkan kontribusi sosial mereka melalui wakaf.

Kemudian, aktivitas penghimpunan dan pendayagunaan wakaf yang dilakukan harus dilaporkan secara rutin baik secara langsung kepada donatur ataupun secara umum ke masyarakat luas melalui laman laporan di website. Laporan yang dipublikasikan di laman website berisi laporan penerimaan dan penggunaan dana, laporan kegiatan yang dijalankan serta progress report dari setiap program wakaf. Laporan khusus donatur wakaf dapat diberikan secara lansung melalui directmail atau silaturahmi doantur. Laporan tersebut berisi rekapan penerimaan donasi dari donatur, penggunaan dana yang telah mereka titipkan, serta para penerima manfaat program wakaf yang dijalankan.

\section{KESIMPULAN DAN SARAN}

\section{Kesimpulan}

Perolehan dan pengelolaan penghimpunan wakaf Pesantren Baitul Hidayah belum optimal, hal itu ditunjukan dengan hasil penghimpunan wakaf dalam 3 tahun terakhir belum mencapai target yang diharapkan khususnya tahun 2018-2019. SDM pengelola wakaf masih merangkap sebagai pengurus pesantren dengan tugas utama sebagai pengajar, sehingga proses pengelolaan wakaf masih berjalan seadanya. Administrasi keuangan dan pendataan donatur belum dilakukan secara sitematis melalui pengelolaan data yang baik dan benar sesuai standar umum lembaga sosial.

Kegiatan dakwah pesantren Baitul Hidayah dalam bentuk pengajian dilakukan oleh para ustad kepada jemaah pengajian baik dari internal maupun eksternal. Jemaah pengajian internal adalah para santri dan orangtua santri. Sedangkan Jemaah pengajian eksternal adalah masyarakat sekitar lingkungan pesantren dan para donatur. Rata-rata setiap ustad memberikan ceramah keagamaan sebanyak 3 kali dalam sebulan. Adapun materi yang disampaikan berkaitan dengan tauhid, fiqh, akhlak, adab, tafsir dan muamalah.

Untuk meningkatkan penghimpunan wakaf, Pesantren Baitul Hidayah dapat melakukan beberapa strategi diantranya : optimalisasi peran dai, penetapan SDM pengelola fulltime, penambahan sarana dan prasana, pengeloaan data, peningkatan layanan donatur serta pelaporan kegiatan pengelolaan wakaf di Pesantren Baitul Hidayah.

\section{Saran}

Berdasarkan hasil analisis data yang diperoleh tentang pengelolaan wakaf maka Pesantren Baitul Hidayah disarankan melakukan perbaikan pengelolaan wakaf mulai dari membangun komitmen bersama para pengurus pesantren tentang pentingnya pengelolaan wakaf, perbaikan kelembagaan seperti branding dan positioning Wakaf Foundation di masyarakat luas sebagai lembaga pengelola wakaf Pesantren Baitul Hidayah, menetapkan petugas atau SDM khusus yang menangani penglolaan wakaf secara fulltime, menyediakan sarana dan prasarana sesuai kebutuhan dan kemampuan, meningkatkan layanan kemudahan kepada para donatur serta memberikan pelaporan kepada masyarakat khususnya para donatur berkaitan dengan penerimaan dan penggunaan dana wakaf. 
Kemudian bagi peneliti selanjutnya, dapat melakukan fokus kajian yang berkaitan dengan peningkatan layanan dan kemudahan berwakaf melalui teknologi informasi. Hasil kajian tersebut dapat berkontribusi bagi Pesantren Baitul Hidayah untuk melakukan pelayanan yang lebih baik kepada para donator.

\section{DAFTAR PUSTAKA}

Abdurrahman Kasdi. 2015. Peran Waqf Produktif Dalam Pengembangan Pendidikan. Jurnal Pendidikan Islam, 3(2), 433-452. https://doi.org/10.21043/QUALITY.V3I2.1917

Ahidul Asror. 2014. Dakwah Transformatif lembaga Pesantren dalam Menghadapi tantangan Kontemporer. Jurnal Dakwah, Vol. XV, No. 2 ; 289-312. https://media.neliti.com/media/publications/76645-ID-dakwah-transformatiflembaga-pesantren-d.pdf

Awaludin Pimay. 2005. Paradigma Dakwah Humanis, Rasail, Semarang.

Arifin Purwakananta. 2010. Peta Kemiskinan : Data Mustahik, Muzakki dan Potensi Pemberdayaan Indonesia. Dompet Dhuafa.

Chaniago. S.A. 2014. Perumusan Manajemen Strategi Pemberdayaan Zakat. Jurnal Hukum Islam (JHI) STAIN Pekalongan, (Online), Vol. 12, Nomor $1 ; 15$.

Departemen Agama, 2007, Fikih Wakaf, Jakarta, Dirjen Wakaf.

Faruq, M.A. Usman, Indrianawati. 2014. Penyusunan Strategi Bisnis Dan Strategi Operasi Usaha Kecil Dan Menengah Pada Perusahaan Konveksi Scissors Di Surabaya. Jurnal Manajemen Teori dan Terapan UNAIR, Vol. 7. No. $3 ; 22$.

Hendi Suhendi. 2018. Optimalisasi Aset Wakaf Sebagai Sumber Dana Pesantren Melalui Pelembagaan Wakaf (studi kasus pelembagaan wakaf pesantren baitul hidayah), Tahkim, jurnal peradaban dan hukum islam. vol.1 no.1 ; 1-20. https://ejournal.unisba.ac.id/index.php/tahkim/article/view/3417

Huda, N. 2012. Keuangan Publik Islam “Pendekatan Teoritis dan Sejarah”. Kencana. Jakarta.

Huda, N., \& Heykal, M. 2010. Lembaga Keuangan Islam Tinjauan Teoritis dan Praktis. Kencana. Jakarta.

Jauhar Faradis, dkk. 2015. Manajemen Fundraising Wakaf Produktif: Perbandingan Wakaf Selangor (PWS) Malaysia dan Badan Wakaf Indonesia. Jurnal Asy-Syir'ah. Vol. 49, No. 2.

Lexy J. Maleong. 1990. “Metode Penelitian Kualitatif”. Rosdakarya. Bandung.

M. Ali Aziz. 2004. Ilmu Dakwah. Prenada Media Kencana. Jakarta.

Mohamad, F., Asmak, S., Rahman, A., Marican, S., Raimi, L., Patel, A., \& Adelopo, I. 2014. The role of share Waqf in the socio-economic development of the Muslim community: The Malaysian experience"Corporate social responsibility, Waqf system and Zakat system as faith-based model for poverty reduction". Humanomics International Journal of Social Economics World Journal of Entrepreneurship 
Jurnal Manajemen dan Bisnis: Performa Vol. 18, No. 2 September 2021

Management and Sustainable Development,30(3),227-254. Retrieved from http://dx.doi.org/10.1108/H-12-2012-0025\%5Cn http://dx.doi.org/10.1108/03068290210413038\%5Cn http://dx.doi.org/10.1108/WJEMSD-09-2013-0052

Muhammad Syaifulloh, 2021. Strategi Program Technopreneurship dan Marketing Public Relation terhadap Pengembangan Usaha Mikro, Kecil dan Menengah (UMKM). Performa Vol. 18, No. 1 ; 1-13.

Peraturan Pemerintah No.28 Tahun 1977 dan Inpres No.1 Tahun 1991

Ridwan, M. 2018. Waqf Dan Pembangunan Ekonomi. ZISWAF : Jurnal Zakat Dan Waqf, 4(1), 105. https://doi.org/10.21043/ziswaf.v4i1.3034

Rodliyah Khuza'I, dkk. 2019. Developing a Waqf Institution through Repairment Management and Insitutional Legalization. Advances in Social Science, Education and Humanities Research, volume $307 . \quad$ https://www.atlantispress.com/proceedings/sores-18/55915278 https://doi.org/10.2991/sores-18.2019.8

Sadeq, A. M. 2002. Waqf, perpetual charity and poverty alleviation. International Journal of Social Economics, 29(1-2), 135-151. https://doi.org/10.1108/03068290210413038

Shaikh, S. A., Ismail, A. G., \& Mohd Shafiai, M. H. 2017. Application of Waqf for social and development finance. ISRA International Journal of Islamic Finance, 9(1), 5-14. https://doi.org/10.1108/IJIF-07-2017-002.

Sukirman, 2020. Strategi Keunggulan Bersaing melalui Keunggulan Asosiasi Merek, Kekuatan Asosiasi Merek dan Keunikan Asosisi Merek. Performa Vol.17, No. 1 ; 14-26.

Syamsuri Siddiq. 1987. Dakwah dan Teknik Berkhuthbah. Al-Ma'arif, Bandung. 